\title{
Field evaluation of introduced and local cowpea genotypes performance in Botswana
}

\author{
Odireleng O. Molosiwa* and Bose C. Makwala \\ Department of Agricultural Research, Ministry of Agricultural Development and Food Security, Private Bag 0033, \\ Gaborone, Botswana.
}

Received 18 June, 2020; Accepted 11 August, 2020

\begin{abstract}
A set of twenty four cowpea (Vigna unguiculata L. Walp) genotypes were evaluated in field conditions for three consequtive seasons based on 13 quantitative characters. A combined analysis of variance revealed a highly significant difference among the genotypes for most of the traits $(P<0.001)$. Introduced genotypes performed better in nine of the characters, revealing the advantage of introduced genotypes. Principal Component Analysis explained a total variation of $76.16 \%$, where the first two PCs accounted for $51 \%$. Most variation was largely dependent from rainfall use efficiency, days to maturity, seed yield per hectare and pod width. Cluster analysis dendrogram delineated the 24 genotypes into two major clusters, with a mixture of local and introduced in both groups which indicated their potential relationship. Exceptional local genotypes B137B, with highest seed yield ( $866 \mathrm{~kg} / \mathrm{ha})$, and the singleton B342 with a number of desirable agronomic traits must be included in future cowpea breeding programs in Botswana.
\end{abstract}

Key words: Cluster analysis, rainfall use efficiency, SPAD reading, Vigna unguiculata.

\section{INTRODUCTION}

Cowpea (Vigna unguiculata (L.) Walp) is a crop with wide global distribution, especially in tropical regions. It is an important grain legume crop in sub-Saharan Africa, with significant production in Nigeria, Burkina Faso, Niger, Cameroon and United Republic of Tanzania (Fatokun et al., 2012; FAOSTAT, 2017). The crop is produced under rain-fed conditions in the drier regions of the world where drought is common due to low and erratic rains (Agbicodo et al., 2009). Cowpea is a high valued crop due to its high quality protein, adaptation to heat and drought, and ability to fix nitrogen. These characters make it a major crop in the context of climate change and food security (Carvalho et al., 2017).

Cowpea is an important cash crop and the main grain legume in Botswana, most production is mainly from small scale farmers under rain-fed conditions. Despite cowpea widespread cultivation, crop yield is low, with an average of $300 \mathrm{~kg} / \mathrm{ha}$, against a potential yield of 2500 $\mathrm{kg} / \mathrm{ha}$. Generally, low cowpea productivity and production is attributed to several factors such as biotic and abiotic

\section{${ }^{*}$ Corresponding author. E-mail: odireleng.molosiwa@gmail.com.}


stress, low yielding varieties, poor soils and poor crop husbandry (plant density) (Olasupo et al., 2016; Mwale et al., 2017). Additional potential constraints of cowpea production could be worsened by climate changes, drastic changes in rainfall patterns, and rise in temperature which could lead to unfavorable growing conditions thereby modifying growing seasons (Ajetomobi and Abiodun, 2010). Therefore, development and adoption of well adapted drought tolerant cowpea varieties that will cope with changing climate conditions is a priority.

International Institute of Tropical Agriculture (IITA) is integral in the development and protection of cowpea and keeps a significant amount of accessions for mining to develop superior performing cultivars (Boukar et al., 2016). The Ministry of Agricultural Development and Food Security, through cowpea breeding program has benefited significantly from this initiative as several cowpea genotypes have been evaluated in Botswana. Varieties ER7 and IT95K6352 sourced from IITA have been evaluated and released for their extra early maturing and early maturing characters, respectively. The other released varieties in the country include Inia 30, Inia 70 and Inia 71 originally from Mozambique (Chiulele, 2010). They have medium maturing characteristics and high yield potential, other varieties released in Botswana include Tswana and Botswana Blackeye. However, several efforts have been made to characterize more than 400 cowpea germplasm accessions collected from many agricultural districts of the country (Molosiwa et al., 2016) with the aim to include more genetic material into the cowpea breeding program. Therefore, the objective of this study was to compare the performance of introduced and local cowpea genotypes under the semi-arid environment of Botswana, and identify well adapted varieties with potential for release.

\section{MATERIALS AND METHODS}

\section{Plant material}

Twenty-four cowpea genotypes with early and medium maturing characteristics and high yield potential were selected for use in the study. Twelve are local lines sourced from the cowpea breeding program but originally from the National Plant Genetic Resource Centre (Botswana), while the other 12 were introduced genotypes from various countries and institutions. The characteristics of the genotypes are described in Table 1.

\section{Study site}

Field experiments were conducted for three consecutive seasons at Sebele Agricultural Research Station, $12 \mathrm{~km}$ north of Gaborone, in Southern Botswana $\left(24^{\circ} 35^{\prime} \mathrm{S} ; 2^{\circ} 56^{\prime} \mathrm{E}\right)$. The area has a unimodal rainfall type that falls between November and April each year. The area receives an average 30-year annual rainfall of $500 \mathrm{~mm} /$ year, with a semi-arid climatic condition. The rainfall received during the growing season of $2012-13$ was $325.3 \mathrm{~mm}$ with an average temperature of $22.8^{\circ} \mathrm{C}$, in $2013-14,327.3 \mathrm{~mm}$ of rainfall was received with a mean temperature of $21.9^{\circ} \mathrm{C}$, while in $2014-15,180$ $\mathrm{mm}$ rainfall was received with a mean temperature of $23.8^{\circ} \mathrm{C}$. The soils in Sebele are shallow tropical soils consisting largely medium coarse texture and sandy loam with low water holding capacity.

\section{Experimental design and crop management}

The soil was ploughed and harrowed with a tractor for land preparation to set up the experiment. A three replicated trial with a randomized complete block design was conducted in a total area of $899 \mathrm{~m}^{2}$. Each plot length was $4 \mathrm{~m}$ with a row spacing of $0.75 \mathrm{~m}$ and within plant spacing of $0.2 \mathrm{~m}$, with a plant population estimates of 67000 plant per hectare. Two seeds were planted per hole and one seedling was left after thinning 21 days after planting. Crop management practice of weeding was adhered to, for the control of pests and disease in the experimental plots.

\section{Agro-morphological characteristics measured}

Morphological and agronomic characters selected were chosen from the International Board for Plant Genetic Resources, IBPGR (1983). Thirteen quantitative traits were recorded which include, days to $50 \%$ flowering (DFF), plant height $(\mathrm{PH})$, pods per plant (PodpPlant), seeds per plant (SeedpPlant), seeds per pod (SeedpPod), pod length (PodL), pod width (PodW), 100 seed weight (100SW), rainfall use efficiency (RUE), seed yield per hectare (YDHA), Spad chlorophyll meter reading (SCMR), shoot dry weight (SDW), days to maturity (DM). At harvest, data were collected within the two middle rows. Shoot dry weight was oven dried for $48 \mathrm{~h}$ at $70^{\circ} \mathrm{C}$ and weighed. Rainfall use efficiency was estimated based on the formula, RUE $=Y / R$ which defines RUE as dry matter accumulated/precipitation in $\mathrm{Kg} \mathrm{ha}^{-1} \mathrm{~mm}^{-1}$, a formula adopted from Wang et al. (2016). Yield ( $Y$ ) is the dry matter accumulated for the cowpeas, while rainfall $(R)$ is the accumulated rainfall for the growing season. Estimates of RUE for each genotype was computed based on the amount of rainfall received per growing season and the seed yield amount. The SCMR measurements were taken at 45 days after sowing using SPAD-502 meter (Minolta, Japan).

\section{Statistical analysis}

Data were subjected to analysis of variance and multivariate statistical analysis was performed for Principal Component and Cluster Analysis to reveal the relationship between the selected cowpea genotypes using Genstat software version 18.0

\section{RESULTS AND DISCUSSION}

\section{Genetic variation of the 24 cowpea genotypes}

A combined analysis of variance indicated a substantial amount of variation for all the 13 quantitative characters among the cowpea genotypes since most traits were highly significant $(P<0.001) \quad($ Table 2$)$. The higher genotypic variability is a great opportunity to identify best performing cultivars. The results concurred with those of Osho and Olasanmi (2018), Araméndiz-Tatis et al. (2018) and Gerrano et al. (2015), who reported statistical differences between cowpea genotypes studied. Most of the characters were not affected by genotype $x$ 
Table 1. Characteristics of the selected cowpea genotypes used in the study.

\begin{tabular}{|c|c|c|c|c|}
\hline Variety & Seed colour & Growth habit $^{b}$ & 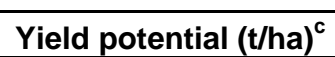 & Origin \\
\hline B097 & Brown & $\mathrm{SP}$ & $1-2$ & Botswana \\
\hline B137B & Reddish brown & $\mathrm{P}$ & $1-2$ & Botswana \\
\hline B138 & Reddish & SP & $1-2$ & Botswana \\
\hline B342 & Tan & $P$ & $1-2$ & Botswana \\
\hline B549 & Tan & $P$ & $1-2$ & Botswana \\
\hline B629 & Tan & $P$ & $1-2$ & Botswana \\
\hline BBLACKEYE ${ }^{\mathrm{A}}$ & White with black-eye & SP & $1.5-2.5$ & Botswana \\
\hline $\mathrm{ER}^{\mathrm{A}}$ & Cream with brown-eye & Erect & $1.5-2.5$ & IITA \\
\hline FARMERV & Tan with brown dots & $\mathrm{P}$ & $1-2$ & Botswana \\
\hline INIA30 ${ }^{\mathrm{A}}$ & Tan & SP & $1.5-2.5$ & Mozambique \\
\hline INIA70 ${ }^{A}$ & Tan & SP & $1.5-2.5$ & Mozambique \\
\hline INIA71 A & Brown & $\mathrm{P}$ & $1.5-2.5$ & Mozambique \\
\hline IT95K107257 & Cream with brown-eye & $\mathrm{P}$ & $1.5-2.5$ & IITA \\
\hline IT95K19312 & Cream with brown-eye & SP & $1.5-2.5$ & IITA \\
\hline IT95K20722 & Brown & SP & $1.5-2.5$ & IITA \\
\hline IT95K6352 ${ }^{\mathrm{A}}$ & Cream with brown-eye & SP & $1.5-2.5$ & IITA \\
\hline IT97K102124 & Cream with brown-eye & SP & $1.5-2.5$ & IITA \\
\hline IT97K10757 & Brown & $\mathrm{P}$ & $1.5-2.5$ & IITA \\
\hline IT97K5641 & Brown & SP & $1.5-2.5$ & IITA \\
\hline IT98K3902 & Reddish brown & $P$ & $1.5-2.5$ & IITA \\
\hline SCAM123 & Tan & $P$ & $1-2$ & Botswana \\
\hline SCAM151 & Reddish brown & SP & $1-2$ & Botswana \\
\hline SCAM190 & Red with black dots & $P$ & $1-2$ & Botswana \\
\hline TSWANA $^{\mathrm{A}}$ & Tan & $\mathrm{P}$ & $1-2$ & Botswana \\
\hline
\end{tabular}

${ }^{A}$ Represent released varieties in Botswana; ${ }^{b} \mathrm{SP}=$ Semi-prostrate; $\mathrm{P}=$ prostrate.

Table 2. Combined analysis of variance for the 13 traits of 24 cowpea genotypes evaluate in the field for three seasons.

\begin{tabular}{|c|c|c|c|c|c|c|c|}
\hline Trait & Season & Rep & Genotype & $G \times S$ & Residual & CV\% & Grand mean \\
\hline $\mathrm{df}$ & 2 & 2 & 23 & 46 & 142 & & \\
\hline Days $50 \%$ flowering & $311.9^{\star *}$ & 59.4 & $232.8^{* *}$ & $13.2^{*}$ & 8.6 & 6.1 & 49.0 \\
\hline Plant height & $1213.9^{\star *}$ & 2712.8 & $278.1^{\star *}$ & $152.0^{* *}$ & 65.8 & 25.4 & 32.0 \\
\hline Pods per Plant & $1254.1^{* *}$ & 1116.0 & $349.7^{* *}$ & $68.6^{\mathrm{ns}}$ & 66.8 & 34.0 & 24.0 \\
\hline Seeds per Plant & $285287^{\star *}$ & 227974 & $9451^{*}$ & $12274^{\star *}$ & 5922 & 58.0 & 133.0 \\
\hline Seed per Pod & $280.6^{* *}$ & 184.7 & $21.6^{\star *}$ & $5.3^{\mathrm{ns}}$ & 6.6 & 25.5 & 10.0 \\
\hline Pod Length (mm) & $10320.4^{\star *}$ & 36876.9 & $1046.2^{* \star}$ & $305.7^{\mathrm{ns}}$ & 381.4 & 14.0 & 139.0 \\
\hline Pod Width (mm) & $2.8^{* *}$ & 5.7 & $4.1^{* *}$ & $0.6^{\mathrm{ns}}$ & 0.5 & 9.3 & 8.0 \\
\hline 100 Seed weight $(\mathrm{g})$ & $59.4^{\star \star}$ & 10.4 & $58.3^{\star *}$ & $3.6^{\mathrm{ns}}$ & 6.4 & 17.1 & 15.0 \\
\hline Seed Yield (kg/ha) & $206220^{\text {ns }}$ & 1983266 & $216850^{*}$ & $86720^{\mathrm{ns}}$ & 129494 & 58.0 & 617.0 \\
\hline $\operatorname{RUE}\left(\mathrm{kg} / \mathrm{ha} \cdot \mathrm{mm}^{-1}\right)$ & $18.1^{\star *}$ & 7.0 & $7.2^{* *}$ & $1.6^{\mathrm{ns}}$ & 2.5 & 59.4 & 2.7 \\
\hline SCMR & $1150.8^{* *}$ & 336.3 & $389.6^{* *}$ & $63.6^{\mathrm{ns}}$ & 107.2 & 20.2 & 51.0 \\
\hline Shoot dry weight (g) & $924.6^{*}$ & 18899.8 & $1218.2^{\star \star}$ & $327.2^{\text {ns }}$ & 369.0 & 37.4 & 51.0 \\
\hline Days to Maturity & $496.3^{* *}$ & 241.6 & $572.3^{* *}$ & $33.3^{\text {ns }}$ & 47.2 & 9.1 & 76.0 \\
\hline
\end{tabular}

d.f. = degrees of freedom; ${ }^{* *}$, highly significant; ${ }^{*}$ significant; ns= non-significant; $\mathrm{G}=$ Genotype; $\mathrm{S}=\mathrm{Season} ; \mathrm{CV}=$ coefficient of variation.

environment interaction with the exception of days to $50 \%$ flowering, plant height, and seeds per plant (Table 2 ), which imply that the performance of the genotypes was consistent across the three seasons, even though there were seasonal differences among most of the traits. The highest coefficient of variation was observed in rainfall use efficiency (59.4\%), seed per plant and seed yield per hectare both at $58 \%$. Similar findings with 
Table 3. The performance of the 24 cowpea genotypes evaluated in the field in Sebele, Botswana based on mean and range for 13 quantitative traits.

\begin{tabular}{lcccc}
\hline \multirow{2}{*}{ Character } & \multicolumn{4}{c}{ Genotypic means } \\
\cline { 2 - 5 } & Local & Introduced & Range & s.e \\
\hline Days 50\% flowering & 51.0 & 46.0 & $41-57$ & 2.9 \\
Plant height (cm) & 33.2 & 31.0 & $24-43$ & 8.1 \\
Pods per plant & 22.6 & 25.6 & $15-42$ & 8.2 \\
Seeds per plant & 133.4 & 131.9 & $83-211$ & 77 \\
Seed per pod & 9.8 & 10.3 & $8-13$ & 2.6 \\
Pod length (mm) & 139.5 & 139.1 & $117-160$ & 19.2 \\
Pod width (mm) & 8.0 & 8.3 & $7-10$ & 0.8 \\
100 seed weight (g) & 14.6 & 15.2 & $11-21$ & 2.5 \\
Seed yield (kg/ha) & 595.1 & 639.3 & $318-866$ & 359.9 \\
RUE (kg/ha.mm-1) & 2.7 & 2.8 & $1.3-4.1$ & 1.61 \\
SCMR & 49.9 & 52.8 & $38-67$ & 10.4 \\
Shoot dry weight (g) & 55.7 & 47.0 & $34-77$ & 19.2 \\
Days to maturity & 78.2 & 73.0 & $65-91$ & 6.9 \\
\hline
\end{tabular}

SCMR: Spad chlorophyll meter reading; RUE: Rainfall use efficiency; s.e: Standard error.

highest coefficient of variations among cowpeas were observed on seed yield per hectare (46.9\%) and seed per plant (44.4\%) by Aliyu and Makinde (2016), which reveals greater variation among these characters. Considerable genetic variability that exists among genotypes was evidenced by a highest range of seed yield (318 - 866 $\mathrm{kg} / \mathrm{ha}$ ), pod length $(117-160 \mathrm{~mm}$ ) and seed per plant (83 - 211) (Table 3). Relatively higher genotype ranges were also reported for seed yield varying from 263.76 to $2624.8 \mathrm{~kg} / \mathrm{ha}$ in South Africa by Nkoana et al. (2019), while seed yield per hectare ranged 522.00 to 2807 $\mathrm{kg} / \mathrm{ha}$, pod length from 10.74 to 22.80 and seed per plant from 64.2 to 360 were reported by Aliyu et al. (2019) in Nigeria. These greater variations indicate a potential for improvement of this crop. The overall average seed yield of $617.0 \mathrm{~kg} / \mathrm{ha}$ (Table 2) is much higher than the national average cowpea production, around $139 \mathrm{~kg} / \mathrm{ha}$ (Statistics Botswana, 2013). However, this average is about the half crop yield of $1270.68 \mathrm{~kg} / \mathrm{ha}$ recorded for cowpea in Nigeria (Aliyu et al., 2019), and much lower than 2043 $\mathrm{kg} / \mathrm{ha}$ for cowpea in Zimbabwe (Matova and Gasura, 2018). Generally, there was a lower seed yield performance among the selected cowpea genotypes as indicated by the grand mean (Table 3 ). This can be attributed to the lower amount of rainfall than the normal amount, that is, $500 \mathrm{~mm}$ for a 30-year annual. However, this was the best time to conduct this research in order to compare the performance of introduced and local cowpea genotypes and identify the best performing varieties, selecting for drought adaptation (Hall, 2002).

\section{Comparison of the performance of local and introduced cowpea genotypes}

A summary of the performance of local and introduced cowpea genotypes is shown on Table 3. Comparatively, on average the local genotypes matured later (78 days), are taller $(33 \mathrm{~cm})$, have higher shoot biomass $(56 \mathrm{~g})$, but with slightly less 100 seed weight $(14.6 \mathrm{~g})$ and seeds per pod (10), and much less seed yield per hectare (595 kg $\mathrm{ha}^{-1}$ ) compared to the introduced improved cowpea genotypes, except genotypes B137B (Table 4). Traits of late maturing plants with high biomass among local genotypes could have been selected by farmers who are mainly interested in the leaf vegetable of the cowpea crop, while the early maturing among introduced lines could be influenced by continued selection for earliness by breeders to reduce the drought effect. A few of introduced genotypes underperformed in some traits, such as lower seed yield (318 kg/ha) on IT95K20722 and lower pod length $(117 \mathrm{~mm})$ by ER7. This could be explained by a lack of adaptation to the arid conditions of Botswana. To improve the pod size of the higher yielding ER7 it would be ideal to hybridize it with those genotypes with larger pods such as B137B and Inia 71 (Table 3).

Most maximum performances were discovered in introduced genotypes such as seed per plant (211), seed per pod (13) and pod length (160 mm) in INIA71, higher pods per plant (42) in IT97K564, higher SCMR (67) and DM (91) in IT95K6352 and higher 100 seed weight $(21 \mathrm{~g})$ in IT95K20722. An equally higher performing of local genotypes was by B137B, which had the highest seed yield $(866 \mathrm{~kg} / \mathrm{ha})$, larger pods sizes of $160 \mathrm{~mm}$ length and $10 \mathrm{~mm}$ width. IITA successfully developed cowpea cultivars with combined stable yield, tolerance to abiotic and biotic stresses with erect or determinate growth habit (Ortiz, 1998; Boukar et al., 2019), as expected would do better than local material with little crop improvement. These results provided evidence of the advantage of introduced cowpea genotypes in the country. Hence, this 
Table 4. A combined summary for the 13 quantitative characters of 24 cowpeas genotypes evaluated in the field condition.

\begin{tabular}{|c|c|c|c|c|c|c|c|c|c|c|c|c|c|}
\hline Variety & $\mathrm{DFF}^{\mathrm{a}}$ & $\begin{array}{l}\mathrm{PH}^{\mathrm{b}} \\
(\mathrm{cm})\end{array}$ & $\begin{array}{c}\text { Podpplan } \\
t^{c}\end{array}$ & Seedp $t^{d}$ & $\underset{d^{e}}{\text { SeedpPo }}$ & $\begin{array}{l}\text { PodL } \\
(\mathrm{mm})\end{array}$ & $\operatorname{PodW}_{g}(\mathrm{~mm})$ & $\begin{array}{l}\text { 100SW } \\
(\mathrm{g})^{\mathrm{h}}\end{array}$ & $\begin{array}{c}\text { YHDA } \\
(\mathrm{kg} / \mathrm{ha})^{\mathrm{j}}\end{array}$ & $\begin{array}{c}\text { RUE } \\
\left(\mathrm{kg} / \mathrm{ha} \cdot \mathrm{mm}^{-1}\right)^{\mathrm{k}}\end{array}$ & $\underset{n}{\text { SCMR }}$ & $\begin{array}{l}\text { SDW } \\
(\mathrm{g})^{\circ}\end{array}$ & $\mathrm{DM}^{\mathrm{p}}$ \\
\hline B097 & 50 & 34 & 24 & 151 & 9 & 146 & 8 & 15 & 629 & 3,1 & 52 & 71 & 72 \\
\hline B137B & 45 & 31 & 20 & 165 & 13 & 160 & 10 & 13 & 866 & 4,0 & 45 & 43 & 70 \\
\hline B138 & 45 & 31 & 22 & 105 & 9 & 143 & 8 & 14 & 772 & 4,1 & 44 & 42 & 68 \\
\hline B342 & 57 & 24 & 17 & 179 & 8 & 119 & 7 & 15 & 778 & 3,7 & 56 & 52 & 87 \\
\hline B549 & 54 & 31 & 26 & 83 & 10 & 142 & 8 & 15 & 451 & 1,7 & 48 & 57 & 83 \\
\hline B629 & 54 & 31 & 24 & 198 & 9 & 134 & 8 & 15 & 554 & 2,1 & 55 & 61 & 86 \\
\hline BLACKEYE & 46 & 43 & 30 & 116 & 9 & 138 & 8 & 16 & 538 & 2,4 & 43 & 41 & 75 \\
\hline FARMERV & 52 & 40 & 21 & 115 & 12 & 145 & 8 & 17 & 329 & 1,3 & 53 & 65 & 78 \\
\hline SCAM123 & 57 & 32 & 19 & 109 & 10 & 129 & 8 & 14 & 444 & 1,8 & 53 & 67 & 86 \\
\hline SCAM151 & 41 & 27 & 20 & 102 & 9 & 146 & 7 & 11 & 587 & 3,0 & 38 & 35 & 65 \\
\hline SCAM190 & 56 & 42 & 20 & 150 & 11 & 128 & 8 & 14 & 505 & 2,3 & 53 & 57 & 84 \\
\hline TSWANA & 55 & 32 & 28 & 128 & 9 & 144 & 8 & 16 & 688 & 2,4 & 59 & 77 & 84 \\
\hline ER7 & 41 & 29 & 23 & 119 & 9 & 117 & 7 & 11 & 780 & 3,8 & 49 & 45 & 66 \\
\hline INIA30 & 44 & 27 & 16 & 137 & 11 & 148 & 9 & 12 & 783 & 3,8 & 51 & 42 & 68 \\
\hline INIA70 & 45 & 27 & 15 & 111 & 11 & 137 & 8 & 12 & 849 & 4,0 & 47 & 37 & 68 \\
\hline INIA71 & 43 & 30 & 26 & 211 & 13 & 160 & 9 & 11 & 743 & 3,1 & 46 & 44 & 65 \\
\hline IT95K107257 & 49 & 34 & 24 & 104 & 9 & 143 & 8 & 16 & 728 & 3,4 & 55 & 61 & 75 \\
\hline IT95K19312 & 45 & 31 & 27 & 159 & 10 & 142 & 9 & 19 & 672 & 2,2 & 61 & 48 & 72 \\
\hline IT95K20722 & 41 & 25 & 38 & 133 & 9 & 127 & 8 & 21 & 318 & 1,3 & 51 & 34 & 68 \\
\hline IT95K6352 & 49 & 38 & 27 & 114 & 8 & 140 & 9 & 15 & 499 & 1,9 & 67 & 50 & 91 \\
\hline IT97K102124 & 47 & 27 & 25 & 89 & 9 & 135 & 8 & 17 & 493 & 1,9 & 56 & 41 & 75 \\
\hline IT97K10757 & 50 & 43 & 25 & 124 & 12 & 136 & 8 & 14 & 688 & 2,6 & 54 & 49 & 73 \\
\hline IT97K5641 & 50 & 28 & 42 & 139 & 10 & 132 & 8 & 20 & 520 & 2,0 & 42 & 54 & 83 \\
\hline IT98K3902 & 48 & 33 & 19 & 143 & 13 & 152 & 9 & 14 & 598 & 3,1 & 54 & 59 & 72 \\
\hline Grand mean & 49 & 32 & 24 & 133 & 10 & 139 & 8 & 15 & 617 & 2,7 & 51 & 51 & 76 \\
\hline LSD (0.05) & 2.7 & 7.6 & 7.6 & 71.7 & 2.4 & 18.2 & 0.7 & 2.4 & 335.3 & 1.5 & 9.6 & 17.9 & 6.4 \\
\hline
\end{tabular}

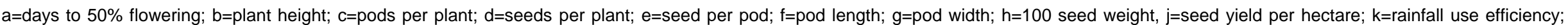
$\mathrm{n}=$ spad chlorophyll meter reading; $\mathrm{o=shoot}$ dry weight; $\mathrm{p}=$ days to maturity.

detailed analysis was able to identify certain local genotypes that could be useful in the cowpea breeding program. Relatively high values of SCMR and RUE in some cowpea genotypes reflect their capacity to photosynthesize and accumulate more dry matter as compared to those with lower values (Al-Barzinji et al., 2015; Muhammad and Massawe, 2015). The highest grain yielding genotypes B137B (866 kg/ha), INIA70 (849 kg/ha), INIA30 (783 kg/ha) and ER7
$(780 \mathrm{~kg} / \mathrm{ha})$ also had higher rainfall use efficiency at $3.8-4.0 \mathrm{~kg} / \mathrm{ha} \cdot \mathrm{mm}^{-1}$ which explain their high yield potential (Table 4). This was consistent with the results of Nkomazana and Batlang (2018) who observed $3.67 \mathrm{~kg} / \mathrm{ha} \cdot \mathrm{mm}^{-1}$ among other cowpea 
Table 5. Principal components, eigenvalues and vectors of the 13 quantitative traits of the 24 cowpea genotypes.

\begin{tabular}{lcccc}
\hline Traits & PC1 & PC2 & PC3 & PC4 \\
\hline Eigenvalue & 4.23 & 2.41 & 2.033 & 1.24 \\
\% Variation & 32.5 & 18.54 & 15.64 & 9.52 \\
Cumulative \% & 32.5 & 51.00 & 66.64 & 76.16 \\
& & & & \\
Latent vectors & & & & -0.019 \\
DFF $^{\mathrm{a}}$ & 0.333 & 0.305 & -0.301 & -0.504 \\
PH $^{\mathrm{b}}$ & 0.145 & 0.298 & 0.096 & 0.227 \\
Pod per plant & 0.217 & -0.243 & 0.431 & 0.608 \\
Seed per Plant & -0.087 & 0.266 & 0.033 & -0.182 \\
Seed per pod & -0.219 & 0.373 & 0.273 & -0.094 \\
Pod length & -0.235 & 0.343 & 0.329 & 0.187 \\
Pod width & -0.136 & 0.402 & 0.394 & 0.270 \\
100SW & 0.329 & -0.142 & 0.334 & 0.265 \\
YHDA $^{\mathrm{d}}$ & -0.364 & 0.100 & -0.282 & 0.123 \\
RUE $^{\dagger}$ & -0.396 & 0.025 & -0.317 & 0.276 \\
SCMR $^{\mathrm{h}}$ & 0.250 & 0.255 & -0.104 & 0.097 \\
DM $^{\mathrm{k}}$ & 0.395 & 0.195 & -0.196 & -0.016 \\
Shoot dry weight $^{\mathrm{c}}$ & 0.274 & 0.365 & -0.179 & \\
\hline
\end{tabular}

$a=$ days to $50 \%$ flowering; $b=$ plant height; $c=100$ seed weight; $d=$ seed yield per hectare; $f=$ rainfall use efficiency; $h=$ spad chlorophyll meter reading; $\mathrm{k}=$ days to maturity.

genotypes from Botswana. Higher values of SCMR were observed in genotypes IT95K6352 (67.0), which is in accordance to those recorded by Abed (2014) in Iran cowpea, were a highest SCMR of 65.6. The highest shoot biomass was observed in local varieties TSWANA $(77 \mathrm{~g})$, B097 $(71 \mathrm{~g})$, SCAM123 $(67 \mathrm{~g})$ and FARMERV (65 g) (Table 4). This indicates that these genotypes are ideal for dual purpose (leafy vegetable and seed grain) and could be further explored for developing high fodder cowpeas. Similarly, dry matter yield per plant had been hailed as a key trait used in the selection for high fodder cowpeas (Naselvakkumaran et al., 2019). The findings also concurred with previous studies that identified the genotypes TSWANA and Blackeye as suitable for leafy vegetable (Karikari and Molatlakgosi, 1999).

\section{Genetic diversity and relatedness of the selected 24 cowpea genotypes}

Principal Component Analysis was used to identify traits that account for most of the variation among the 24 genotypes. The eigenvalues $>1$ were selected and used to define the 13 agro-morphological traits (Table 5). The first four PCA explained a total variation of $76.16 \%$, with the first two PCs accounting for $51 \%$ of variation. These results further support the variation observed in the analysis of variance in Table 2 . Characters that contributed mostly to the variation in PC1 (32.5\%) in descending order are: RUE, day to maturity, seed yield per hectare, days to $50 \%$ flowering and 100 seed weight; in PC2, accounting for $18.54 \%$ variation it was mainly pod width, seed per pod, shoot dry weight and pod length; PC3 contributing to $15.64 \%$ variation was mainly influenced by pods per plant, pod width, 100 seed weight, and pod length, while seed per plant and plant height were the main contributor in the last PC4 $(9.56 \%)$ (Table $5)$. The findings are in accordance to those by Nkoana et al. (2019) who reported a total variation of $78.20 \%$ among the first 4 PCs, where the first two PCs accounted for $50.2 \%$ of variation. They also identified influential traits such as number of seeds per pod, 100 seed weight, pod length and grain yield.

A hierarchical cluster analysis dendrogram for the 24 cowpea genotypes based on the 13 traits shows an overall similarity of 1 to 0.8 (Figure 1). The dendrogram clustered the genotypes into two main groups at 0.825 Euclidean distances. The first cluster consists of 16 genotypes ranging from genotype B097 to B342, and this include equal number of both introduced and local genotypes within the cluster excluding the B342 which is an outlier within the first group. This reveals high phenotypic similarity between the local and introduced material, and the low genetic diversity within groups. This could be influenced by the fact that cowpea is predominantly a self-pollinating crop and is expected to a certain degree of heterozygosity (Badiane et al., 2012). Cluster 2 consists eight genotypes (five introduced) which consists all the three genotypes from Mozambique and the three locals (B137B, B138, SCAM151), and these are 


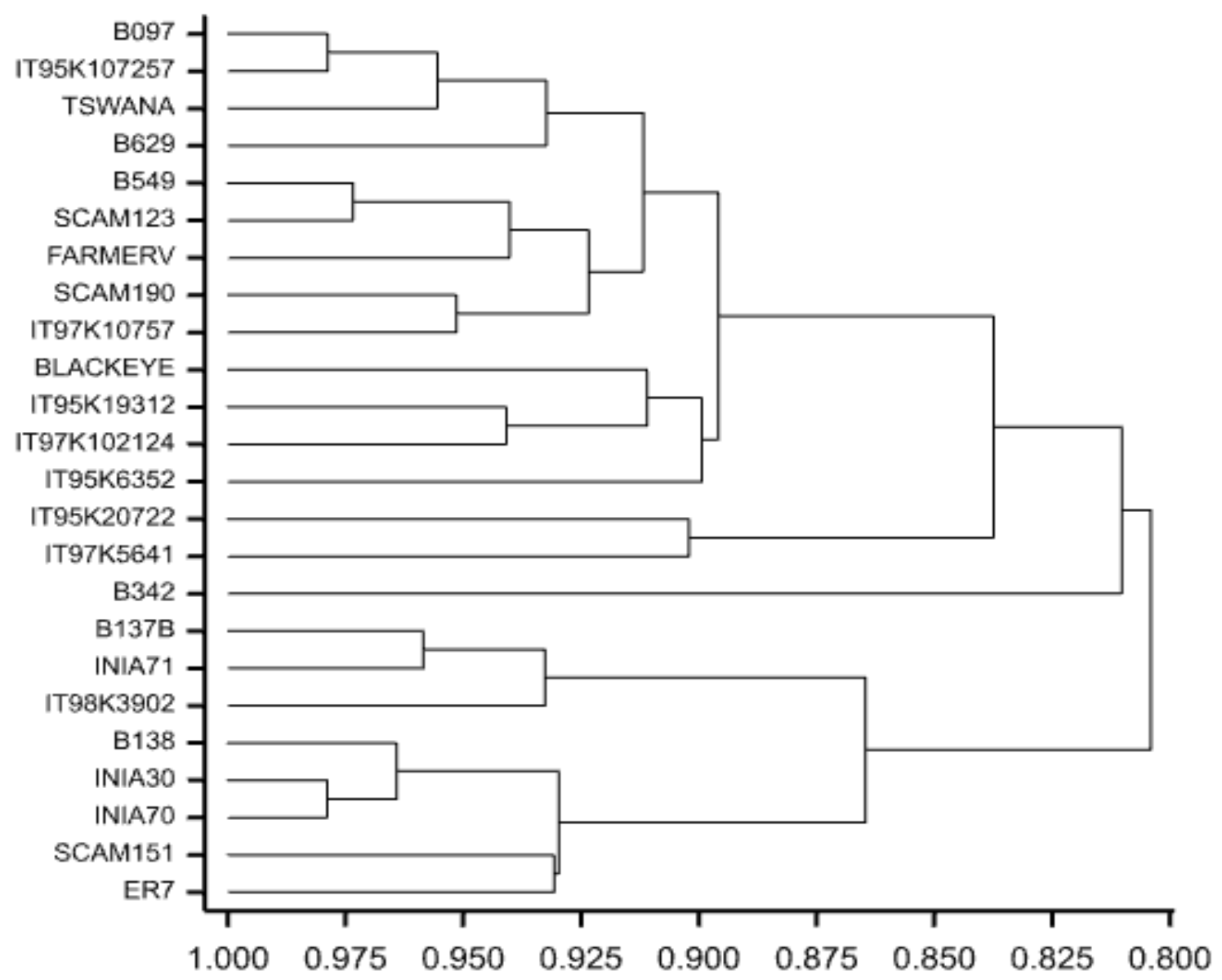

Figure 1. Dendrogram of 24 cowpea genotypes showing a similarity cluster analysis based on 13 agromorphological traits in a field experimental condition in Sebele, Botswana.

generally high performers. The clusters have been delineated mainly based on traits with higher loadings as defined in Table 5, such as seed RUE, day to maturity and seed yield per hectare. The cluster analysis revealed some similarities between local and introduced cowpeas, such as among (B137B and INIA71), and also (B097 and IT95K107257) as shown in Figure 1. For further genetic improvement it would be ideal to conduct some hybridization between the clusters to improve cowpea genotypes in Botswana. Genotype B342 which is an outlier is more diverse and should be prioritized in selection. It was the last one to reach $50 \%$ flowering, had the lowest plant height, lowest number of seeds per pod and lowest pod width, but was among the top 5 best seed yield producers, with $778 \mathrm{~kg} / \mathrm{ha}$ (Table 4). Therefore, selection of desirable traits in this genotype could assist to improve it. Farmer variety is genetically similar to other local cowpea genotypes such as SCAM123 and B549 (Figure 1), and it yield relatively low at $329 \mathrm{~kg} / \mathrm{ha}$, and flowered late, longer than 50 days for $50 \%$ flowering (Table 4). Similarly, Aliyu et al. (2019) observed that farmer varieties are well adapted to low input conditions, poor yielders, indeterminate, mature late and are susceptible to biotic and abiotic conditions. Joseph (2014) argued that farmers continue growing their low yielding varieties of cowpea because they prefer specific traits of interest such as grain quality, taste or leafy vegetables. These are some of the traits that plant breeders will have to incorporate in their breeding program to develop farmer preferred varieties.

\section{Conclusion}

In this research, based on thirteen selected traits the best performing varieties were identified. Even though the introduced cowpeas have a relatively better performance, two local genotypes, B137B and B342, were among the top five in terms of seed yield per hectare. Overall, the study revealed that the local cowpea genotypes compared well with some introduced lines. Introduced genotypes with larger seeds such as IT95K20722 will be useful sources of genes for other cowpeas and this could be useful for market acceptability This results could also 
have implications in selection in the local cowpea breeding program based on the performance of the best varieties such as, B137B and B342 which are not yet released to be evaluated for on-farm under participatory variety selection.

\section{CONFLICT OF INTERESTS}

The authors have not declared any conflict of interests.

\section{REFERENCES}

Abed AZ (2014). Breeding for drought tolerance in progenies of cowpea (Vigna unguiculata (L.) Walp). Journal of Experimental Biology and Agriculture Sciences 2(5):490-494.

Agbicodo EM, Fatokun CA, Muranaka S,Visser RGF, Linden van der CG (2009). Breeding drought tolerant cowpea: constraints, accomplishments and future prospects. Euphytica 67:353-370.

Ajetomobi J, Abiodun A (2010). Climate change impacts on cowpea productivity in Nigeria. African Journal of Food Agriculture Nutrition and Development 10(3):2258-2271.

Al-Barzinji IM, Khudhur SA, Anwar AM (2015). Spectrophotometric method using different solvents and SPAD chlorophyll meter for determination some photosynthesis pigments of bean and cowpea plants. International Journal of Engineering Technology Management and Applied Sciences 3:108-113

Aliyu OM, Lawal OO, Wahab AA, Ibraham UY (2019). Evaluation of advanced breeding lines of cowpea (Vigna unguiculata L. Walp) for high yield under farmer's field conditions. Plant Breeding and Biotechnology 7(1):12-23.

Aliyu OM, Makinde BO (2016). Phenotypic analysis of seed yield and yield components in cowpea (Vigna unguiculata L. Walp). Plant Breeding and Biotechnology 4(2):252-261.

Araméndiz-Tatis $\mathrm{H}$, Cardona-Ayala $\mathrm{C}$, Espitia -Camacho M, ArrietaPuche D, Barba AG (2018). Estimation of genetic parameters in white seed cowpea (Vigna unguiculata L. Walp.). Australian Journal of Crop Science 12:1016-1022.

Badiane FA, Gowda BS, Cissé N, Diouf D, Sadio O, Timko MP (2012). Genetic relationship of cowpea (Vigna unguiculata) varieties from Senegal based on SSR markers. Genetics and Molecular Research 11(1):292-304.

Boukar O, Belko N, Chamarthi S, Togola A, Batieno J, Owusu E, Haruna M, Diallo S, Umar ML, Olufajo O, Fatokun C (2019). Cowpea (Vigna unguiculata): Genetics, genomics and breeding. Plant Breeding 138:415-424.

Boukar O, Fatokun CA, Huynh BL, Roberts PA, Close TJ (2016). Genomic tools in cowpea breeding programs: status and perspectives. Frontiers in Plant Science 7:1-13.

Carvalho Muñoz -Amatriaín M, Castro I, Lino-Meto T, Matos M, EgeaCortines M, Rosa E, Close T, Carnide V (2017). Genetic diversity and structure of Iberian Peninsula cowpeas compared to world -wide cowpea accessions using high density SNP markers. BMC Genomics pp. 18:1-9.

Chiulele RM (2010). Breeding cowpea (Vigna unguiculata L. (Walp.) for improved drought tolerance in Mozambique, PhD, Thesis. African Centre for Crop Improvement School of Agricultural Sciences and Agribusiness. Faculty of science and Agriculture, University of Kwazulu-Natal. Republic of South Africa.

FAOSTAT (2017). Food and Agriculture Organization. Available at: www.fao.org/faostat/en/hashtagcountry

Fatokun CA, Boukar O, Muranaka S (2012). Evaluation of cowpea (Vigna unguiculata (L.) Walp.) germplasm lines for tolerance to drought. Plant Genetic Resources 10(3):171-176.
Gerrano AS, Adebola PO, van Rensburg WSJ, Laurie SM (2015) Genetic variability in cowpea (Vigna unguiculata (L.) Walp.) genotypes. South African Journal of Plant and Soil 32(3):1-10.

Hall E (2002). Phenotyping cowpeas for adaptation to drought. Frontiers in Physiology 3(155):1-8.

International Board for Plant Genetic Resources (IBPGR) (1983). Rome, Italy, International IBPGR. Vigna Unguiculata, Secretariat Rome. www.biodiversityinternational.org

Joseph BTB (2014). Breeding for drought tolerance in cowpea [Vigna unguiculata (L.) Walp.] using marker assisted back crossing, Ph. D. thesis. West Africa Centre for Crop Improvement School of Agriculture College of Basic and Applied Sciences, University of Ghana Legon, Ghana.

Karikari SK, Molatlakgosi G (1999). Response of cowpea (Vigna unguiculata (L.) Walp) varieties to leaf harvesting in Botswana. UNISWA Journal of Agriculture 8:5-11.

Matova PM, Gasura E (2018). Yield and stability of new cowpea variety in Zimbabwe. African Crop Science Journal 26:277-289.

Molosiwa OO, Gwafila C, Makore J, Chite SM (2016). Phenotypic variation in cowpea (Vigna unguiculata [L.] Walp.) germplasm collection from Botswana. International Journal of Biodiversity and Conservation 8(7):153-163.

Muhammad YY, Massawe F (2015). Photosynthetic gas exchange and chlorophyll in bambara groundnut (Vigna subterranea L. Verdc.) subjected to water deficit. Bayero Journal of Pure and Applied Sciences 8(1):50-55.

Mwale SE, Ochwo-Ssemakula M, Sadik K, Achola E, Okul V, Gibson P, Edema R, Singini W, Rubaihayo P (2017). Response of cowpea genotypes to drought stress in Uganda. American Journal of Plant Sciences 8(4):720-733.

Naselvakkumaran T, Babu S, Sudhagar R, Sivakumar SD (2019). Interrelationship and Path coefficient analysis of fodder yield and yield components traits in fodder cowpea (Vigna unguiculata L. Walp.). Electronic Journal of Plant Breeding 10(2):720 -726.

Nkoana DK, Gerrano AS, Gwata ET (2019). Agronomic performance and genetic Variability of cowpea (Vigna unguiculata) accessions. Legume Research- An International Journal 42(6):757-762.

Nkomazana C, Batlang U (2018). Grain yield water use efficiency of cowpea (Vigna unguiculata L. Walp.) in response to planting dates in Botswana. In: Revermann R, Krewenka KM, Schmiedel U, Olwoch $\mathrm{JM}$, Helmschrot J, Jürgens $\mathrm{N}$ (eds), Climate change and adaptive land management in southern Africa - assessments, changes, challenges, and solutions: Klaus Hess Publishers, Göttingen and Windhoek. 2018. Biodiversity and Ecology 6:282-287.

Olasupo FO, llori CO, Forster BP (2016). Mutagenetic effects of Gamma Radiation on eight accessions of cowpea (Vigna unguiculata (L.) Walp.). American Journal of Plant Sciences 7(2):331-251.

Ortiz R (1998) Cowpeas from Nigeria: A silent food revolution. Outlook on Agriculture 27(2):125-128.

Osho T, Olasanmi B (2018). Genetic variability among cowpea (Vigna unguiculata L. Walp.) mini core collection. Asian Journal Research in Crop Science 2(4):1-10.

Statistics Botswana (2013). Statistics Botswana. Annual agricultural survey report, Statistics Botswana, agricultural statistics unit, Ministry of Finance and Development Planning, Department of Printing and publishing, Gaborone.

Wang X, Jia Z, Liang L, Yang B, Ding R, Nie J, Wang J (2016). Impacts of manure application on soil environment, rainfall use efficiency and crop biomass under dryland farming, Scientific Reports 6(20994):1-8. 